Histoire Épistémologie Langage

\section{Histoire Épistémologie Langage}

43-2| 2021

Linguistique psychologique et sémiotique : le contexte allemand et son influence

\title{
Ouvrages de collaborateurs d'HEL
}

Publications by associates of HEL

\section{(2) OpenEdition}

\section{Journals}

Édition électronique

URL : https://journals.openedition.org/hel/1494

DOI : $10.4000 /$ hel. 1494

ISSN : 1638-1580

\section{Éditeur}

Société d'histoire et d'épistémologie des sciences du langage

\section{Édition imprimée}

Date de publication : 31 décembre 2021

Pagination : 227-228

ISBN : 9791091587150

ISSN : 0750-8069

\section{Référence électronique}

" Ouvrages de collaborateurs d'HEL », Histoire Épistémologie Langage [En ligne], 43-2 | 2021, mis en ligne le 01 décembre 2021, consulté le 17 décembre 2021. URL : http://journals.openedition.org/hel/ 1494 ; DOI : https://doi.org/10.4000/hel.1494

Ce document a été généré automatiquement le 17 décembre 2021.

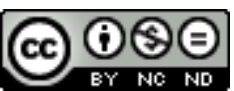

HEL is licensed under a Creative Commons Attribution-NonCommercial-NoDerivatives 4.0 International License 


\title{
Ouvrages de collaborateurs d'HEL
}

\author{
Publications by associates of HEL
}

\section{NOTE DE L'ÉDITEUR}

Les « collaborateurs d'HEL » sont les membres du laboratoire HTL ainsi que les membres du bureau de la SHESL. Leurs ouvrages ne peuvent donner lieu à compte rendu dans HEL.

"Associates of HEL" refers to members of the HTL research unit and to members of the SHESL board. Their publications may not be reviewed in HEL.

Textes réunis par Laurent Cesalli, Frédéric Goubier, Anne Grondeux, Aurélien Robert, Luisa Valente. 2021. Ad placitum : pour Irène Rosier-Catach. 2 vol. Arricia : Aracne editrice (Flumen sapientiae, 14). 684 p. ISBN : 978-8-8255-3913-4.

1 Ce volume est un florilège libre des manières dont les ami-e·s, élèves et collègues d'Irène Rosier-Catach ont souhaité rendre hommage à son œuvre comme à sa personne. En dépit de son titre en forme de mot d'ordre - ad placitum - l'ensemble de ces 87 textes traite, sous un rapport ou un autre, de la thématique centrale des travaux d'Irène Rosier-Catach, à savoir le langage. La diversité des formes et des langues reflète la très large et riche communauté qui s'est formée autour d'elle. Une publication atypique, pour une figure hors du commun.

Léon, Jacqueline. 2021. Automating Linguistics. Cham: Springer (History of Computing, XV). 179 p. ISBN: 978-3-0307-0641-8.

2 Automating Linguistics offers an in-depth study of the history of the mathematisation and automation of the sciences of language. In the wake of the first mathematisation of the 1930s, two waves followed: machine translation in the 1950s and the development of computational linguistics and natural language processing in the 1960s. These waves were pivotal given the work of large computerised corpora in the 1990s and the unprecedented technological development of computers and software. Early machine translation was devised as a war technology originating in the sciences of war, amidst the amalgamate of mathematics, physics, logics, neurosciences, acoustics, and emerging sciences such as cybernetics and information theory. Machine translation 
was intended to provide mass translations for strategic purposes during the Cold War. Linguistics, in turn, did not belong to the sciences of war, and played a minor role in the pioneering projects of machine translation. Comparing the two trends, the present book reveals how the sciences of language gradually integrated the technologies of computing and software, resulting in the second-wave mathematisation of the study of language, which may be called mathematisation-automation. The integration took on various shapes contingent upon cultural and linguistic traditions (USA, ex-USSR, Great Britain and France). By contrast, working with large corpora in the 1990s, though enabled by unprecedented development of computing and software, was primarily a continuation of traditional approaches in the sciences of language sciences, such as the study of spoken and written texts, lexicography, and statistical studies of vocabulary.

Velmezova, Ekaterina, éd. 2020. La discussion linguistique de 1950: 70 ans après. Lausanne \& Moscou: Faculté des lettres, Unil \& индрик (Epistemologica et historiographica linguistica Lausannensia, 2). 194 p. ISBN : 978-5-9167-4626-6.

3 Les auteurs du recueil - des chercheurs venant de Suisse, de Russie, de Géorgie, de France, d'Estonie et de Finlande - partagent leurs réflexions sur un événement d'il y a soixante-dix ans: la célèbre discussion linguistique ayant eu lieu en 1950 en Union soviétique et qui a radicalement changé la situation dans les sciences humaines soviétiques. Les articles, publiés en russe, en français et en anglais, discutent du contexte général de l'époque qui a engendré la discussion, des langues et des «traditions linguistiques nationales » soviétiques qui ont été influencées d'une manière ou d'une autre par la discussion ou qui sont évoquées dans celle-ci, ainsi que de la réception de la discussion en Occident. 